\title{
Medical Ideals in the Sephardic Diaspora: Rodrigo de Castro's Portrait of the Perfect Physician in early Seventeenth-Century Hamburg
}

\author{
JON ARRIZABALAGA
}

\section{Introduction}

As is well known, there were no formal systems of medical ethics until the end of the eighteenth century. Yet at least from the composition of the Hippocratic Oath, western scholarly debates, particularly among doctors, on the foundations of good medical practice and behaviour produced written works. These works simultaneously reflected and contributed to setting customary rules of collective behaviour - medical etiquette - that were reinforced by pressure groups who, while they could not always judge and sentence offenders, sanctioned them with disapproval. Most early modern works on medical etiquette were dominated by the question of what constituted a good medical practitioner, with the emphasis sometimes on the most suitable character of a physician, sometimes on professional behaviour. ${ }^{1}$

The medical literary genre of the perfect physician appears to have been popular in the early modern Iberian world, and the frequent involvement of converso practitioners in writing about it has often been associated with the peculiarities of their professional position in the territories under the Spanish monarchy. ${ }^{2}$ Among the most outstanding examples

This article has been prepared within the framework of the research project BHA2002-00512 of the Spanish Ministry of Science and Technology.

I am indebted to Enrique Cantera Montenegro, Andrew Cunningham, Teresa Huguet-Termes and Sebastià Giralt for their advice and material assistance.

\footnotetext{
${ }^{1}$ See the entry 'Medical ethics, history of Europe', particularly the sections 'Ancient and medieval' (by Darrel W Amundsen) and 'Renaissance and Enlightenment' (by Harold J Cook) as well as the bibliography referred to there, in Stephen G Post (ed.), Encyclopedia of bioethics, 3rd ed., 5 vols, New York, Macmillan Reference USA, 2004, vol. 3, pp. 1555-83, 1583-9.

${ }^{2}$ See, for example, Julio Caro Baroja, Los judios en la España moderna y contemporánea, 2nd ed., 3 vols, Madrid, Istmo, 1978, vol. 2, pp. 200-4. On the world of Iberian converso practitioners, see, among others, Caro Baroja, op. cit., vol. 2, pp. 175-204, 205-25; Diego Gracia Guillén, 'Judaism, medicine, and the inquisitorial mind in sixteenth-century Spain', in Angel Alcalá (ed.), The Spanish Inquisition and the inquisitorial mind, New York, Columbia University Press, 1987, pp. 375-400; Yosef Kaplan, From Christianity to Judaism: the story of Isaac Orobio de Castro, Oxford and New York, Oxford University Press, 1989; David B Ruderman, 'The community of converso physicians: race, medicine, and the shaping of a cultural identity', in idem, Jewish thought and scientific discovery in early modern Europe, New Haven and London, Yale University Press, 1995, pp. 273-309; Jon Arrizabalaga, 'The world of Iberian converso practitioners, from Lluís Alcanyís to Isaac Cardoso', in Víctor Navarro Brotóns and William Eamon (eds), Más allá de la leyenda negra: España y la revolución científica / Beyond the black legend: Spain and the scientific revolution, Valencia, Instituto de Historia de la Ciencia y Documentación López Piñero (Universitat de València-CSIC), 2007, pp. 307-22.
} 


\section{Jon Arrizabalaga}

of this medical genre are a couple of printed works written by two Portuguese Jewish physicians who were almost exactly contemporary with each other, namely Henrique Jorge Henríques $(c .1555-1622)^{3}$ and Rodrigo de Castro (c.1546-1627). ${ }^{4}$ Despite similarities, their images of the ideal medical practitioner appear to have been modified somewhat by each author's differing life experiences and career, as I will show later on.

De Castro's life and works have been treated in a very limited and rather traditional way by historians, mostly according to the patterns of disciplinary history both medical and medical-ethical as well as of Jewish national history. ${ }^{5}$ Indeed, he has repeatedly been introduced as one of the founding fathers of modern gynaecology and obstetrics, as a medical ethicist well ahead of his time and, in particular, as an outstanding example of a singular, almost idiosyncratic excellence, that has supposedly characterized the professional practice of Jewish physicians throughout history. ${ }^{6}$

The present essay is an attempt to approach De Castro's intellectual agenda in the context of the Sephardic medical diaspora, by exploring the portrait of the perfect physician that he drew in his Medicus-politicus. His views on the ideal medical practitioner need to be placed in the social context of the early modern European medical world and, specifically,

\footnotetext{
${ }^{3}$ Henrique Jorge Henríques, Retrato del perfecto médico, Salamanca, en casa de Juan y Andrés Renaut impressores, 1595. For an overview of Henríques' biography and his Retrato, see Jon Arrizabalaga, 'The ideal medical practitioner in Counter-Reformation Castile: the perception of the converso physician Henrique Jorge Henríques (c.1555-1622)', in Samuel S Kottek and Luis García-Ballester (eds), Medicine and medical ethics in medieval and early modern Spain: an intercultural approach, Jerusalem, Magnes Press, 1996, pp. 61-91. Henríques' Retrato has been dealt with by, among others, Caro Baroja, op. cit., note 2 above, pp. 201-2; Gracia Guillén, op. cit., note 2 above, passim; Winfried Schleiner, Medical ethics in the Renaissance, Washington, DC, Georgetown University Press, 1995, passim; David Linden, 'The perfect physician: 16th century perspectives from the Iberian peninsula', Sudhoffs Archiv, 2000, 84: 222-31, on pp. 224-5.

${ }^{4}$ Rodrigo de Castro, Medicus-politicus, sive de officiis medico-politicis tractatus, quatuor distinctus libris: in quibus non solum bonorum medicorum mores ac virtutes exprimuntur, malorum vero fraudes et imposturae deteguntur..., Hamburg, ex Bibliopolio Frobeniano, 1614.

5 On Rodrigo de Castro's life and works, see Antonio Hernández Morejón, Historia bibliográfica de la medicina española, 7 vols, Madrid, Imp. de la Vda. De Jordán-Imp. de la Calle de San Vicente, 1842-1852 (facsimile reprint: New York and London, Johnson Reprint Corporation, 1967), vol. 1, pp. 107-8; Anastasio Chinchilla, Anales históricos de la medicina en general y biográfico-bibliográficos de la española en particular, 4 vols, Valencia, Imp. López y Cía-Imp. Mateu y Cervera, 1841-1846 (facsimile reprint: New York and London, Johnson Reprint Corporation, 1967), vol. 1, pp. 82-4; Moritz Kayserling, 'Rodrigo de Castro', in Isidore Singer (ed.), The Jewish encyclopedia, 12 vols, New York, Funk and Wagnalls, 1901-1906, vol. 3, pp. 611-12; Harry Friedenwald, 'The doctors De Castro', in idem, The Jews and medicine: essays, 2 vols, Baltimore, Johns Hopkins Press, 1944, vol. 2, pp. 448-59; Hans-Joachim Schoeps, 'Die Arztfamilie de Castro.

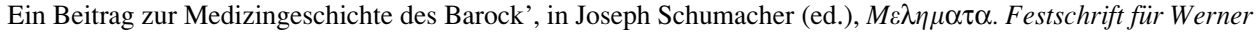
Leibbrand zum siebzigsten Geburstag, Mannheim, Mannheimer Grossdruckerei, 1967, pp. 123-8; Caro Baroja, op. cit., note 2 above, vol. 2, pp. 179, 187, 194-5, 202-3. More recently, De Castro's Medicus-politicus has been discussed by Gracia Guillén, op. cit., note 2 above, passim, in the context of the rise of political medicine; by Schleiner, op. cit., note 3 above, passim, in the context of medical ethics in Renaissance Europe; and by Ruderman, op. cit., note 2 above, pp. 294-9, as a part of the early modern Jewish quest for cultural identity.

${ }^{6}$ In the classic The Jewish contribution to civilisation (London, Macmillan, 1938), Cecil Roth introduced De Castro as "one of the fathers of medical jurisprudence", the author "of one of the first books on the subject", and claimed that "his De universa mulierum morborum medicina (1603) ... is generally regarded as having laid the foundations of gynaecology as we know it to-day" (p. 202). More recently, Schleiner (op. cit., note 3 above, pp. 68, 72-3, 86) has uncritically and anachronistically introduced Rodrigo de Castro, David de Pomis and other early modern Jewish practitioners of the diaspora as champions of "natural religion" and of humanitarian and secularized medicine, allegedly in contrast to the sectarian positions held by their contemporary colleagues both Catholic and Protestant. For a recent discussion on the spread of the attribution to Jews of a "conspicuous involvement in and propensity for scientific achievement", see Ruderman, op. cit., note 2 above, pp. 1-13.
} 
in that of early seventeenth-century Hamburg. ${ }^{7}$ In order to understand better De Castro's views, I will outline the vicissitudes of his life, beginning with his medical training at Salamanca University in about the mid-1560s. As we will see, far from any essentialist view about identities (Jewish or otherwise), De Castro's intellectual profile was a typical example of the mutual fluid exchange of identities between the "new Christians" and the "new Jews". This feature, which is easily detectable among early modern Sephardim, expressively illustrates the open, dynamic and complex nature of the processes of the configuration of identities, as well as the basic role that cultural diversity and mixing usually play in them. ${ }^{8}$

Still in terms of preliminary considerations, and in the light of the profound revision that the predominant historiographic paradigm of the "scientific revolution" has experienced during the last decades, ${ }^{9}$ I propose in my investigations of Rodrigo de Castro and other early modern Jewish physicians and philosophers not to be restricted by questions such as to what extent (if any) and why they participated in the scientific revolution, or whether the Jewish religion was an advantage or a disadvantage for this purpose. Rather, Iberian converso physicians' activities should be re-situated in their specific socio-cultural context; and the intellectual "world" of these practitioners should be reconstructed in the most comprehensive way, particularly in connection with their educational background. The debt that these historiographic approaches owe to the new social and cultural history is clear, because of the greater prominence and complexity that these figures gain when they are studied through this new perspective, and because of the greater power of these strategies to reconstruct the past of Iberian medicine and science.

\section{Rodrigo de Castro in the Context of the Sephardic Diaspora}

Between the mid-fifteenth and the late-seventeenth century, the fortune of Jews in the Iberian kingdoms went through serious vicissitudes, which to a great extent

\footnotetext{
${ }^{7}$ For recent useful approaches to the early modern European medical world and its peculiarities, see among others, Harold J Cook, Trials of an ordinary doctor: Joannes Groenevelt in seventeenth-century London, Baltimore, Johns Hopkins University Press, 1994; Laurence Brockliss and Colin Jones, The medical world of early modern France, Oxford, Clarendon Press, 1997; Andrew Wear, Knowledge and practice in English medicine, 1550-1680, Cambridge University Press, 2000; Mary Lindemann, Medicine and society in early modern Europe, Cambridge University Press, 1999.

${ }^{8}$ On this question see, for example, Yosef Hayim Yerushalmi, De la corte española al gueto italiano: marranismo y judaísmo en la España del siglo XVII: el caso de Isaac Cardoso, Madrid, Turner, 1989, pp. 2142 (chapter 1); Yosef Kaplan, Judios nuevos en Amsterdam: estudios sobre la historia social e intelectual del judaísmo sefardí en el siglo XVII, Barcelona, Gedisa, 1996, particularly pp. 23-77. The two chapters included in these pages were first published by Kaplan as 'Political concepts in the world of the Portuguese Jews of Amsterdam during the seventeenth century: the problem of exclusion and the boundaries of self-identity', in Yosef Kaplan, Henry Méchoulan and Richard H Popkin (eds), Menasseh Ben Israel and his world, Leiden, Brill, 1989, pp. 45-62; and Yosef Kaplan,'The Portuguese community in 17th century Amsterdam and the Ashkenazi world', in Jozeph Michman (ed.), Dutch Jewish History Vol. II. 4th Symposium on the history of the Jews in the Netherlands entitled "Interactions and interrelations": selected papers..., Jerusalem, Institute for Research on Dutch Jewry, The Hebrew University, 1989, pp. 23-45.

${ }^{9}$ See, for example, David C Lindberg and Richard S Westman (eds), Reappraisals of the scientific revolution, Cambridge, Cambridge University Press, 1990; H Floris Cohen, The scientific revolution: a historiographical inquiry, Chicago and London, Chicago University Press, 1994; Margaret J Osler (ed.), Rethinking the scientific revolution, Cambridge, Cambridge University Press, 2000; Navarro Brotóns and Eamon (eds), op. cit., note 2 above.
} 


\section{Jon Arrizabalaga}

determined the further history of this minority. Among them, one should emphasize first, the setting up of a new Inquisition in Spain (1478) and Portugal (in 1536, though fully in operation only after the papal bull of 1547) whose main original purpose was the prosecution of crypto-Judaism or Marranism; second, a gradual implementationin the kingdoms under the Hispanic monarchy from the mid-fifteenth century, and in Portugal from the period of Iberian Union (1580-1640) under the aegis of Castile- of the statutes of "purity of blood" that legalized the social exclusion of new Christians, by blocking or making very difficult their access to any public position or high honour; third, the expulsion from the Iberian kingdoms of those Jews who were not prepared to comply with the decrees of forced Christian conversion dictated by the kings of both crowns - the Catholic Monarchs in 1492, and King Manoel I in 1497; and fourth, the two Sephardic diasporas: the first resulting in the late-fifteenth-century expulsions from Spain and Portugal towards the eastern Mediterranean and northern Africa, and the second, throughout the sixteenth century and on into the eighteenth, towards different places in western Europe-Italy (Venice, Verona, Livorno), the Low Countries (Antwerp, Amsterdam), southern France (Bordeaux, Bayonne), London, and Hamburg - and the Indies, both West (Caribbean area, Brazil) and East (Goa).

The almost forty years that elapsed between the enactment of the edict that forcibly expelled the Jews from Portugal (1497) and the setting up of the Inquisition in that country, helps to explain the strong cohesion of Portuguese Jewish communities in the following centuries, in contrast to the greater uprooting of the Spanish ones. ${ }^{10}$ On the other hand, an awareness of the changing political relationships between the two Iberian crowns throughout the sixteenth and seventeenth centuries is essential for an understanding of the migratory flows of the Jewish population back and forth between the territories of the two crowns. These occurred because of the need, on the one hand, to avoid Inquisitorial repression, and, on the other, because of the emigrants' fluctuating expectations for their own socioeconomic improvement in one or other of the two kingdoms. So, for instance, the rigours of the Portuguese Inquisition after Portugal's annexation to the Hispanic crown by Philip II (1556-1598) meant that many descendants of Jews expelled by the Catholic monarchs who had taken refuge in Portugal and been obliged to convert to Christianity in 1497 escaped back to Spain where the converso question at that time provoked less virulence. Furthermore, Philip IV (1621-1665) offered for a while very attractive socio-economic opportunities to the Portuguese "new Christians" who migrated to Spain, despite the rapid worsening of the living conditions of these immigrants after the revolt that enabled the kingdom of Portugal to recover its independence from Spanish dominion in $1640 .^{11}$

Rodrigo de Castro was born in Lisbon about $1546^{12}$ into a well-off converso family, several members of which were physicians, including his father and three maternal uncles.

\footnotetext{
${ }^{10}$ Yerushalmi, op. cit., note 8 above, pp. $23-4$.

${ }^{11}$ Richard L Kagan, Students and society in early modern Spain, Baltimore and London, Johns Hopkins University Press, 1974, pp. 90-2; Henry Kamen, Inquisition and society in Spain in the sixteenth and seventeenth centuries, London, Weidenfeld and Nicolson, 1985, pp. 221-31.

${ }^{12}$ His birth date appears rather uncertain, namely 1546, according to Maximiano Lemos (Zacuto Lusitano: a sua vida e a sua obra, Porto, E Tavares Martins, 1909, p. 230), Harry Friedenwald (op. cit., note 5 above, p. 449), and the Wellcome Library catalogue of printed books; before 1547, according to Hernández Morejón, as he claimed that De Castro had died on 20 January 1627 aged more than eighty (op. cit., note 5 above, p. 108); 1550, according
} 


\section{Rodrigo de Castro's Portrait of the Perfect Physician}

One of them, Manoel Vaez, was royal doctor to four successive Portuguese kings, namely João III (1521-1557), Sebastião (1557-1578), Henrique I the Cardinal (1578-1580) and Philip II. Another of his uncles, Ayres Vaez, was sent by João III, his master, to Africa in the late 1530s to cure the king of Fez from a serious illness, while both kings were waging a bloody war against each other. ${ }^{13}$ Vaez's apparent professional success in this mission did not prevent him some years later from losing the royal favour and being tried before the Inquisition as a crypto-Jew, although he was eventually given his liberty by Paul III-a pope well known for showing favour towards the Jews-who in 1541 issued a bull that protected the entire Vaez family from the Inquisition. ${ }^{14}$

Originally a Spanish and Portuguese Jewish lineage with many branches, the De Castro family soon spread widely through Europe (Bordeaux, Bayonne, the Low Countries, and Hamburg), mostly as a result of the pressure of the Inquisition. Rodrigo de Castro was the most distinguished physician of this lineage. According to his own account, he studied medicine at the University of Salamanca, whose surgical teaching by Andrés Alcázar and the commentary on the Hippocratic Prognostics by Juan Bravo de Piedrahita he praised. ${ }^{15}$ Yet, it is uncertain where he got the degrees of doctor of philosophy and medicine that on the title-page of his Medicus-politicus he claimed to hold. ${ }^{16}$

Once De Castro had finished his studies in 1570, he returned to Portugal and practised medicine first in Évora and then in Lisbon, where he settled for a while. His growing professional reputation made Philip II-the new king of Portugal after 1580-invite him to move to the East Indies in order to continue the research on medicinal herbs that had previously been carried out by two other Portuguese converso physicians: Garcia da Orta (c.1501/2-1568) from the 1530s until his death, and Cristovão da Costa/Cristóbal Acosta (c.1515-post 1592) between 1568 and 1572, when Da Costa returned to Portugal. De Castro appears to have been offered a good salary and honours in return for gathering the medicinal simples growing in all the Oriental provinces of the Portuguese crown, along with those described by Greek and Arab authorities, and for writing a commentary on them. Nevertheless, he firmly declined the royal invitation. ${ }^{17}$

to The Jewish encyclopedia (op. cit., note 5 above, p. 611), and Ruderman (op. cit., note 2 above, p. 295); and 1541 according to the National Library of Medicine catalogue of printed books.

13 "Fessanus Rex aegrotans a Lusitaniae Rege Joanne tertio, cum quo bellum gerebat crudelissimum, medicum postulavit, qui meum avunculum, cui idem, quod mihi nomen fuit, eo liberalissime misit, hoc adjungens, ut omnem adhiberet diligentiam ac sedulitatem in curatione barbari Regis, cujus ope liberatus fuit a gravissimo morbo." See Rodrigo de Castro, Medicus-politicus, Hamburg, ex Bibliopolio Frobeniano, 1662, liber III, caput 15, p. 167.

${ }^{14}$ The Jewish encyclopedia, op. cit., note 5 above, vol. 12, p. 394.

${ }^{15}$ De Castro, op. cit., note 13 above, pp. 68, 82. Andrés Alcázar (1490-1585) was professor of surgery at Salamanca University from 1567, when this chair was created. Juan Bravo de Piedrahita (1517-1610) held successively the chairs of Articella (1560-1563) and of Avicenna (1563-1597). De Castro wrongly referred to Juan Bravo de Piedrahita as "Pedro Bravo".

16 "Roderici a Castro, Lusitani, Philos.[ophiae] ac Medic.[inae] Doct.[oris] per Europam notissimi, MedicusPoliticus, sive de officiis medico-politicis tractatus ...". There is no mention of De Castro among the medical students in sixteenth-century Salamanca inventoried by Teresa Santander, Escolares médicos en Salamanca (siglo XVI), Salamanca, Europa Artes Gráficas, 1984.

${ }^{17}$ De Castro, op. cit., note 13 above, pp. 194-5: "Idem Philippus ac reliqui Hispaniae Lusitaniaeque Reges plurimam pecuniam impenderunt medicamentis convehendis ex utraque India ac undique terrarum, et medicinalibus viridariis excolendis. In quem finem voluerunt, ut ego quamvis indignus in Indiam Orientalem navigarem oblato stipendio amplo, et honoribus non contemnendis, quibus hoc etiam additum erat, ut neque Proregi, neque cuipiam alii addictus essem, quin immo ipse teneretur, ex omnibus Orientis provinciis curare, ad me deferri 
At some point in the 1580s, and apparently on religious grounds due to growing inquisitorial pressure-although he may not have felt too comfortable after having declined the royal offer-Rodrigo de Castro left Portugal for Antwerp, where he probably lived for a while and gained high esteem as a medical practitioner. ${ }^{18}$ There he met Henrique Rodrígues, another Portuguese converso colleague whose kinswoman, perhaps a sister, Catharina Rodrígues, he married. After the Spaniards recovered control of Antwerp in $1585,{ }^{19}$ he may have moved to the safer northern Netherlands (perhaps to Amsterdam, the greatest Jewish community in Europe at the time) and possibly lived there for several years.

Finally, De Castro moved to Hamburg where he may have taken up residence in 1594right at the time when this city was becoming a significant settlement for Portuguese Jewish refugee families, and for a growing colony of the Amsterdam Jewish community. His professional services on the occasion of a devastating plague epidemic in Hamburg in 1596 , on which he published a little medical work that very year, ${ }^{20}$ allowed him to win a good standing among the local population as well as recognition from the Hamburg political authorities. In this regard, De Castro followed the path of other Jewish medical practitioners who took advantage of most doctors' flight when the plague crisis broke out, in order to gain the favour of the municipal authorities. ${ }^{21}$ His plague treatise should be considered not only the result of his medical concerns, but also as a source of income and a way of self-promotion in a highly demanding context for this sort of medical literature. ${ }^{22}$ De Castro never held the position of city physician at Hamburg that he doubtless aspired to, but his medical reputation continued to grow both there and in the regions and states around this city republic. His medical clientele would include several princes and other distinguished persons, including the King of Denmark, the Archbishop of Bremen, the Duke of Holstein, the Duke of Mecklenburg, and the Landgrave of Hessen.

In Hamburg, his two elder sons were born and his first wife died in about 1602 as a result of her third childbirth. This premature loss may have influenced De Castro's publication of De universa mulierum medicina (Hamburg and Cologne, 1603-1604), a lengthy medical treatise in two volumes on women's "nature" and diseases. ${ }^{23}$ Ten years later, when he was

simplicia, quae ibi crescunt, ego vero illa conferrem cum iis, de quibus Graeci et Arabes scripserunt, et ad eorum capita reducerem, edito de iisdem commentario. Quod utique munus tametsi honorificum, et universo orbi utilissimum, justis de causis detrectavi, sperans fore, ut alius, qui me et eruditione et experientia superet, idipsum aliquando perficiat."

${ }^{18}$ According to Lemos (note 12 above, pp. 225, 230-3), De Castro's professional activities at Antwerp are evidenced by many references in his works to Belgian women's customs and illnesses.

${ }^{19}$ Between 1585 and 1589 Antwerp lost almost half its population, which declined from 80,000 to 42,000 inhabitants (Encyclopaedia Britannica, Macropaedia XIII, 15th ed., 1990, p. 866).

${ }^{20}$ Rodrigo de Castro, Tractatus brevis de natura et causis pestis, quae hoc anno MDXCVI Hamburgensem civitatem affligit ..., Hamburg, Jacobus Lucius Junior, 1596. This work was addressed to the Hamburg Senate.

${ }^{21}$ Contrary to anachronistic interpretations about how most physicians usually fled from medieval and early modern cities and towns during plague epidemics, it should be taken into account that only those contracted by the political authorities were then legally and morally obliged to stay. See Patrick Wallis, 'Plagues, morality and the place of medicine in early modern England', English Historical Review, 2006, 121 (490): 1-24.

${ }^{22}$ Instances of plague treatises intended for similar purposes are those written by Lluís Alcanyís (c.1440-1506) and Andrés Laguna (c.1511-1559). See Jon Arrizabalaga (ed.), Lluís Alcanyís. Regiment preservatiu e curatiu de la pestilència, Barcelona, Edicions Barcino, 2008; Miguel Ángel González Manjarrés, Andrés Laguna y el humanismo médico: estudio filológico, Valladolid, Junta de Castilla y León, 2000, pp. 110-2.

${ }^{23}$ Rodrigo de Castro, De universa mulierum medicina, 2 vols, Hamburg and Cologne, Officina Frobeniana at Philip de Ohr's printing press, 1603-1604. The first volume (De natura mulierum) consists of four books where he 
almost in his seventies and about the time his elder son Benedict was beginning his university medical education, De Castro published his Medicus-politicus (Hamburg, 1614), ${ }^{24}$ a treatise that his biographer Moritz Kayserling characterized as a genuine medical testament. ${ }^{25}$

While in Hamburg, De Castro showed at first a nominal attachment to the Church and, indeed, his first wife was buried in the Catholic cemetery of this city republic. Yet, in 1612 his name was included in the list of Hamburg's Jewish community ${ }^{26}$ along with those of his second wife, his two elder sons from his first wife-both of whom would become physicians ${ }^{27}$ - and three other small children from the new wife. In fact, De Castro would eventually recover the faith of his ancestors to the point that in 1614-the very year of his Medicus-politicus - he appears to have written in Portuguese a treatise on herem (Jewish excommunication or anathema). ${ }^{28} \mathrm{He}$ died on 20 January 1627, and was buried in the cemetery of the Jewish Portuguese congregation at Altona. ${ }^{29}$

Given that the right to residence was officially granted to Jews in Hamburg only in February 1612 (albeit with some restrictions), it seems clear that De Castro joined his Jewish brethren early. Rather interestingly, well-off Jewish fugitives from the Portuguese Inquisition began to settle in 1590s Hamburg as Portuguese "traders". For a while, they professed Judaism in an increasingly open way, but continued to have their children baptized. In the face of the Lutheran citizenry's growing hostility to the Portuguese Jews, in 1617 the Hamburg senate chose to enlarge the minority's trade privileges at

successively dealt with the anatomy of the uterus and breasts; semen and menses; coitus, conception and pregnancy; and labour and breastfeeding. The second volume (De morbis mulierum) focuses on women's diseases, including those that were then considered as peculiar to widows and virgins, those related to pregnancy and pregnant women, and the ones that women in childbirth and wet-nurses may suffer from. Also instrumental in consolidating his career in Hamburg appears to have been De Castro's success in treating the illness of the wife of Balthasar de Alefeld, governor of Felsenburg, since this gained him the favour of this influential family. See Lemos, op. cit., note 12 above, pp. 231-2.

${ }^{24}$ De Castro, op. cit., note 4 above.

${ }^{25}$ See Lemos, op. cit., note 12 above, p. 232.

${ }^{26}$ In 1612 this community consisted of 125 adults, among whom there were ten merchants, two physicians, and three artisans. See Heinrich Graetz, Bella Löwy and Philipp Block, 6 vols, History of the Jews, Philadelphia, The Jewish Publication Society of America, 1949, vol. 4, p. 388.

${ }^{27}$ They were Benedict/Baruch Nahmias (1597-1684) and Andreas/Daniel de Castro (born in 1599; medical degree taken at Padua in 1633), who would become physicians to Queen Christina of Sweden (1645) and to King Christian IV of Denmark, respectively. See Ruderman, op. cit., note 2 above, pp. 299-308.

${ }^{28}$ Rodrigo de Castro, Tratado de Herem, em o qual a serca desta materia . . . cited also under the title Trattado da Halissa, en o qual sen a desta materia dialogixxv, this apparently lost work is mentioned by Moritz Kayserling, Biblioteca española-portugueza-judaica: dictionnaire bibliographique des auteurs juifs, Strasbourg, Trubner, 1890 (facsimile ed.: Madrid, Ollero \& Ramos, 2000), pp. 36-7. On the herem among Iberian Jews, see Enrique Cantera Montenegro, Aspectos de la vida cotidiana de los judios en la España medieval, Madrid, UNED, 1998, p. 192. If this lost treatise by De Castro were a work concerning cases and circumstances in which herem could be imposed, its author might have been a rabbi or, at least, somebody with authority in the Jewish community of Hamburg. Yet the fact that in numerous Jewish communities of sixteenth- and seventeenth-century Europe there was a strong reaction against an abusive imposition of herem, also allows us to hypothesize that this work could well have argued this. Indeed, because of De Castro's peculiar identity of being a "new Jew" and his rationalist medical profile, he might have been tempted, like other Iberian crypto-Jews of the western European Sephardi diaspora who reverted to Judaism, to make theological and philosophical proposals that could very often have been perceived as heterodox. With regard to this, see Kaplan, op. cit., note 2 above, on the illustrative case of Isaac Orobio de Castro.

${ }^{29}$ Friedenwald, op. cit., note 5 above, p. 451. Yet, Lemos (op. cit., note 12 above, pp. 225, 232) held that De Castro was still alive in 1629 , allegedly because of a letter he wrote to Abraham Zacuto on 16 July that year. 
the expense of their civic rights, as they were forbidden to possess houses and lands, and obliged to part with the properties they owned before that law was passed. In recognition of the services rendered to the city of Hamburg, its senate partly exempted De Castro from complying with this law. ${ }^{30}$

\section{Rodrigo de Castro's Portrait of the Perfect Physician}

As advertised on its title-page, the subject matter of the Medicus-politicus was those aspects or functions of medical practice which were related to the republic's governmental tasks. This work of De Castro's maturity was addressed to “practitioners, patients, those attending them, and every cultivator of letters, particularly those involved in the discipline of government", and from its presentation it clearly aimed to draw attention to the virtues of good physicians and to denounce the frauds and impostures of bad physicians, all this with the purpose of restoring the pristine magnificence of medicine. ${ }^{31}$ De Castro announced his hope of contributing to the public utility as much as to his sons' expected medical training, as well as of letting coming generations of physicians know his contribution to the task of codifying medical practice. He claimed that his Medicus-politicus was based not only on the authorities quoted but also, and above all, on the findings and experiences of his own long career as a medical practitioner. And he even claimed to be the first to have written such a medical work in which theory, practice, precepts and the conditions of the perfect physician were combined. ${ }^{32}$ De Castro's Medicus-politicus was dedicated to two senators of the Hamburg republic, ${ }^{33}$ who he promised would be remembered by future doctors for having been patrons of his planned code. ${ }^{34}$

The treatise is divided into four books or parts of uneven length, where, with some thematic inconsistencies, a great number of questions concerning what nowadays we would define as medical ethics and etiquette are formulated and discussed. In book I, ${ }^{35}$ De Castro defined medicine, compared it with other disciplines like jurisprudence, agriculture, and the military art, and debated its pre-eminence over jurisprudence, in addition to refuting the "medical sects" and other opponents of allegedly genuine medicine. In book II, ${ }^{36}$ he established medicine's origins, its relationships with other health practices (mostly surgery and pharmacy), the disciplines requisite for physicians, and the indispensable items of an ideal medical library; and he also opened a wide discussion on a number of epistemic questions (relevance of experience, reason, and authority_Galen's "three doctrines"). In book III, ${ }^{37}$

\footnotetext{
${ }^{30}$ Not even Rodrigo de Castro was allowed to bequeath his house to any heir. See Graetz, et al., op. cit., note 26 above, vol. 4, pp. 685-8. For a general overview of Jewish physicians in early modern Germany, see John M Efron, Medicine and the German Jews: a history, New Haven and London, Yale University Press, 2001, pp. 34-63, 280-9.

${ }^{31}$ De Castro, op. cit., note 13 above, signat. A1r.

${ }^{32}$ Ibid., signats. A2v-A3r, p. 1. Curiously enough, about twenty years before, Henrique Jorge Henríques had made similar claims in favour of his Retrato del médico perfecto. See Henríques, op. cit., note 3 above, pp. 9-10.

33 “Amplissimis, clarissimis, et sapientissimis viris, domino Vincentio Mollero J.U.L. peritissimo, et domino Hieronymo Vogelero, florentissimae reipublicae Hamburgensis Consulibus vigilantissimis, Rodericus a Castro, philosophus ac doctor medicus, S.P.D ....”. See De Castro, op. cit., note 13 above, signat. A2r.

34 "Altera hujus instituti causa fuit, ut posteriores medici vobis acceptas referant eas leges, quae sub vestro patrocinio publici juris factae sunt.” Ibid., signat. A3r.

${ }^{35}$ Ibid., pp. 1-53. Book I includes 12 chapters.

${ }^{36}$ Ibid., pp. 53-209. Book II includes 15 chapters.

${ }^{37}$ Ibid., pp. 110-205. Book III includes 24 chapters.
} 


\section{Rodrigo de Castro's Portrait of the Perfect Physician}

De Castro enumerated and characterized the "virtues" required in the perfect physician as well as the "vices" medical practitioners should avoid; he also defined the ways false physicians can be identified; and dealt with general questions about clinical relationships (clothes, look, way of approaching the patient and his/her assistants, ways of establishing prognoses, particularly from urine, use of clinical information from the face of the patient, medical consultations, sanctions for malpractice, honoraria, gifts and favours), and on to the appropriate behaviour of practitioners in the face of peculiar clinical circumstances, such as those concerning insane, hopeless, ungrateful, and hostile patients, as well as those who have not asked for medical attention. Finally, in book IV, ${ }^{38}$ he discussed questions concerning irregular practices (fascination, love philtres, and incantations), medico-legal expertise (people who pretend to be ill, poisoning, head injuries, drowning, lost virginity, sterility, and the purchase of slaves), and a heterogeneous set of issues such as macro- and microcosmic correlations, the analogy between the human body and a "well-ordered republic", the occult properties of things, and the therapeutic powers of music.

Much of the contents of De Castro's Medicus-politicus are commonplace in pre-modern western medical ethics and etiquette, so to speak. Its narrative is firmly rooted in the Galenic-Avicennan medical tradition, and is established on the Hippocratic ideals of the medical practitioner and practice, with a remarkable degree of Judaic religious and moral influence. Among the sixty-seven chapters making up this work, a peculiar structure is repeated, the roots of which lie in scholastic logic, and are witness to De Castro's university training at Salamanca during the 1560s. Its chapters, whose titles themselves often consist of a scholastic quaestio, usually begin by exposing a number of different views about the topic under discussion. Then, arguments in favour and against these views are presented, and these alternative opinions are usually refuted. Finally, De Castro formulates and justifies his conclusions on each issue discussed. The narrative is often peppered with examples taken from the authorities of learning, who reflect not only his university arts and medical training, but also his wide knowledge of Old Testament sources. Yet he was not very generous with explicit references to specific anecdotes or episodes from his own professional experience, despite having claimed at the very beginning of his work that this was the main source feeding his narrative. This feature, which contrasts with the contents of Henríques' and other contemporary writings on similar subjects, may have followed from De Castro's claim-expressed in the prologue letter addressed to the two Hamburg senators-to confer on his Medicus-politicus the prescriptive value of a code for medical professional behaviour.

\section{Male, Virtuous, and Expert in Medicine}

Rodrigo de Castro's shaping of the perfect physician began by defining him as "male, virtuous, and expert in medicine". ${ }^{39}$ What did he understand by each of the ingredients in his definition? The first and most obvious is the perfect physician's male condition. As one might expect, the single regular function he assigned to women as health practitioners was that of midwives (obstetrices), who played an auxiliary role to a physician's professional

\footnotetext{
${ }^{38}$ Ibid., pp. 205-77. Book IV includes 16 chapters.

39 "Medicus est vir bonus medicinae peritus". Ibid., p. 3.
} 


\section{Jon Arrizabalaga}

activities, and whom, by the way, he did not always differentiate clearly from the reviled sluts (mulierculae), ${ }^{40}$ to whom he repeatedly referred. ${ }^{41}$ In the remaining passages of Medicus-politicus where women were also mentioned, they appeared as patients, as attendants to patients - who were usually their husbands - or mediators in clinical relationships, and as the most usual agents or victims of fascination. ${ }^{42}$

From the first pages of Medicus-politicus, it is clear through De Castro's emphasis on the relevant feature that physicians were endowed with wisdom by nature, as much as with art by training. Only through these qualities could the required fusion be achieved between knowledge and virtue in consonance with the demands of the Hippocratic medical ideal. This justified, therefore, his reminder that "in the old days the science of healing was considered as a part of wisdom, so that the cure of diseases and the contemplation of natural and moral things rose from the same authors". ${ }^{43}$ De Castro was concerned to refute Pietro d'Abano's view that physicians, because of their nature and of the celestial bodies dominating medicine, were usually neither good nor wise persons, but of bad habits. ${ }^{44}$ And he did it by means of arguments that discredited judiciary astrology, showed the probity of customs of most eminent medical authorities ("Hippocrates, Galen, Avicenna, Celsus and others"), and emphasized the theological and medical incongruence implied by associating such a beneficial art with its allegedly depraved practitioners. ${ }^{45}$

\section{The Nobility and Origins of Medical Art}

De Castro's own definition of medicine as "an art based on reason and experience to obtain and preserve health" ${ }^{46}$ led him to make profession of a Hippocratic-Galenic faith,

\footnotetext{
40 “Id vero, quod glossator ait, medicos non esse majoris precii quam obstetrices, omnino repugnat verbis ipsius decreti, quae sunt majoris auctoritatis, ubi medici nobiliores fuerant declarati, quam jureconsulti, quam nobilitatem glossator ipse [André Tiraqueau], insertis illis verbis, voluit attenuare : In le ge, vero, si duobus vel tribus, medici non aestimantur ut obstetrices, sed favore quodam obstetricibus conceditur eadem portio, quae medicis, quod potius in honorem medicorum, quam in eorundem ignonimiam cedit, siquidem etiam mulierculis, quia medicinam exercere videntur, eadem portio attribuitur, quae medicis fuerat concessa, et idem jus cum professoribus artium liberalium, quae omnia ad medici dignitatem pertinent; quippe qui non solum sint honorandi, verum etiam eorundem ministri atque ministrae obstetrices, qua ratione principum servis domini privilegia communicantur." Ibid., p. 46.

${ }^{41}$ Ibid., pp. 154, 163, 198, 203, 205.

${ }^{42}$ Ibid., pp. 128-9, 149-50, 154, 202-3, 249 (patients); 155, 163, 165-6 (attendants or mediators); 205-11, 216, 223 (agents or victims of fascination and love-philtres). De Castro also referred to the custom of Japanese women (sic) ("in India Orientali Japonicae mulieres") being burned with their husbands when the latter died. Ibid., pp. 247-8.

43 ،... olim medendi scientia sapientiae pars habebatur, ut et morborum curatio et rerum naturalium moraliumque contemplatio sub iisdem autoribus nata sit ...". Ibid., p. 3.

44 "Est autem sciendum quod medici merito utplurimum malorum extant morum. Tum quia ex vili stipite, et sterili originem contraxerunt, intumescentes demum, et contumeliosi facti cum fuerint aliqualiter incrassati. Tum etiam quia medicinae scientia, et simpliciter curativa maxime Scorpioni attributa est, et Marti, quorum proprietates in malum tendentes iam sunt tactae. Conservativa vero magis Tauro, et Veneri, hos in omnem trinam incitantibus luxuriam, istos tamen qui stellariter pravorum morum existunt propter virtutem Scorpionis, et Martis in eis dominantem ob attributionis virtutem perfectos reperio medicos." See Pietro d'Abano, Conciliator controversiarum, quae inter philosophos et medicos versantur, Venice, apud Iuntas, 1565 (facsimile reprint: Padua, Antenore, 1985), fol. 10vb (dif. VII). Interestingly enough, Huarte de San Juan attributed to Jewish physicians a similar moral ambiguity. On this issue, see Ruderman, op. cit., note 2 above, pp. 285-93.

${ }^{45}$ De Castro, op. cit., note 13 above, pp. 5-8.

46 " [Medicinae definitio] . . . ars cum ratione, et experientia faciendae conservandaeque sanitatis ...". Ibid., p. 4.
} 


\section{Rodrigo de Castro's Portrait of the Perfect Physician}

and to attack the empiricist and methodist sects, whose theoretical bases and patterns of practice he refuted with a number of arguments. ${ }^{47}$ To the rejection of these two old medical sects, he added a third contemporary one, that of the chemists, whose origin he ascribed to Paracelsus, and whose rapid spread through Europe he noted with great alarm. Like many other European university practitioners of his time, ${ }^{48}$ he was concerned about marking the scholastic difference between the followers of Paracelsus on the one hand, and, on the other, the pharmacists in charge of preparing drugs according to physicians' prescriptions, whom he respected and defined as "true chemists" (verus chymista). He blamed the "new and superstitious medicine" of the chemists for preferring novelty to truth, and of infesting the "well-ordered republic" with new principles and causes of diseases that implied the rejection of those owed to the ancients, and the consignment to oblivion of Hippocrates' and Galen's philosophy and medicine. ${ }^{49}$ In his diatribe against chemical medicine, De Castro responded to Paracelsus' claim to have found the principles of things in the Holy Scriptures, by echoing the accusation, widespread among the contemporary medical establishment, ${ }^{50}$ that Paracelsus had prepared the remedies prescribed for epilepsy by means of a magic art taken from evil spirits-necromancy. ${ }^{51}$

After having rejected several arguments from a variety of sources-explicit in the cases of Cato and Pliny the Elder-questioning the need for medicine and its practitioners, De Castro vindicated the antiquity of this art and its constant presence, in one form or another, among all the ancient peoples. ${ }^{52}$ He referred the origins of medicine to the God of the Old Testament, through the words of the well-known passage in Ecclesiasticus (38: 1-15), where medicine and physicians are praised, and he said that the divine origins of this art are to be combined with the obligation that men apply themselves to cultivate medicine and to search for natural remedies in order to preserve or restore health. ${ }^{53}$ Against those who categorized medicine as a vile profession because medical practitioners were required to manipulate such coarse and filthy things as bodily discharges, both natural and unhealthy, De Castro held that medicine was a science of a noble, superior order, for its theoretical part refers to physics - just as politics does to jurisprudence, and metaphysics to theologywhile its practical part pursues something so useful and fruitful as the recovery and preservation of human health. $^{54}$

De Castro vindicated the origins of medicine for the Jewish people on the basis of the above mentioned passage of Ecclesiasticus, and on the huge work by the wise king Solomon on natural questions, including medicine-which was allegedly destroyed at the burning of the temple of Jerusalem by Nebuchadrezzar II (605-562 BCE)—without

${ }^{47}$ Ibid., pp. 9-14.

${ }^{48}$ A useful overview of early modern medical reactions to Paracelsians has been provided for the French case by Brockliss and Jones, op. cit., note 7 above, pp. 119-28.

${ }^{49}$ De Castro, op. cit., note 13 above, pp. 14-19.

${ }^{50}$ For this accusation against Paracelsus, see, for example, the influential work by Thomas Erastus (15231583), Disputationum de medicina nova Paracelsi. Pars I: In qua quae de remediis superstitiosis et magicis curationibus prodidit praecipue examinantur, Basel, Petrus Pernae, 1572, p. 140. Cf. Walter Pagel, Paracelsus: an introduction to philosophical medicine in the era of the Renaissance, 2nd ed., Basel, Karger, 1982, p. 329.

${ }^{51}$ De Castro, op. cit., note 13 above, p. 19.

${ }^{52}$ Ibid., pp. 20-9.

${ }^{53}$ Ibid., pp. 29-34.

${ }^{54}$ Ibid., pp. $34-7$. 


\section{Jon Arrizabalaga}

omitting the idea that the earliest information on medical matters dated from Adam himself. However, echoing the words of Georgius Cedrenus, an eleventh-century Byzantine chronicler, he argued that king Ezechias of Judah (726-697 BCE), was offended because the Jews, although provided by these works with the remedies for diseases, forgot to praise God for curing them, and instead offered medicine to the Greeks. ${ }^{55}$

\section{The Ideal Medical Library}

To De Castro, this early ceding of medicine to the Greeks did not cancel the Jews' original primacy in this art, but marked a turning point in the history of medicine. Indeed, his indispensable library for the "perfect physician" had as its mainstays three groups of "most proven writers": the Greeks, the Latins, and the Arabs. All were presided over by a trio made up of Hippocrates, "supreme father of medicine", Galen, "from whose works you can perfectly grasp medicine", 56 and Avicenna, whom he described as the architect of the structure of medicine. ${ }^{57}$ Among the Greeks, De Castro included ancient classical authorities (Hippocrates, Plato, Aristotle, Theophrastus, Dioscorides, and Galen) as much as post-classical and Byzantine medical writers (Aretaeus of Cappadocia, Oribasius, Alexander of Tralles, Paul of Aegina, Aetius of Amida and Joannes Actuarius). Among the Latin medical writers, he first mentioned Cornelius Celsus-whom he called the "Latin Hippocrates"- and then Scribonius Largus, Pliny the Elder, Quintus Serenus, Caelius Aurelianus and Theodorus Priscianus. Last but not least, among the Arabs, he referred, in the first place (inprimis [sic]), to Avicenna, ${ }^{58}$ and then to Averroes, Rhazes, Avenzoar, Mesue and Serapion. ${ }^{59}$

De Castro defined as insane the view of those who had reviled the Arab medical tradition, and he vindicated its legacy outright, among other reasons because Arab physicians flourished at a difficult time when "the best disciplines remained deeply deserted and buried", and they did not teach religion but medicine. Against the drastic anti-Arabism of most Hellenist physicians, he put forward the case of Jean Fernel who, without denying Averroes' and Avicenna's supposedly obscure phrasing, is introduced as having defended

\footnotetext{
${ }^{55}$ Ibid., pp. $74-7$.

56 "Est enim Hippocrates magnus profecto adeo maximus medicinae parens, et in quo artificii totius semina insunt sed cujus animi sensa, praeclara illa quidem, verum concisa nimis brevitate, at aetate illa fortasse usitata litteris tradita fuerunt; huius itaque magni viri aphorismi, prognostica, phrophetica et epidemiorum libri, ac de morbis acutis non solum perlegendi saepius sunt, sed memoriae commendandi. Galenus vero is est quem nocturna diuturnaque manu versare oportet, ejus opera accurate evolvere, ex quibus justam concipere medicinae notitiam possis." Ibid., pp. 84-5.

57 "Similiter etiam architectonicen esse medicinam quandam, et imperatricem, non solum quod multos dicto oboedientes habeat, verum etiam ac longe quidem magis, quod architecti, regisque atque imperatoris optimi more rectam secum rerum suarum validamque, atque inconcussam rationem constituens, menteque eam atque intellectu stabiliter firmans, leges ipsa sibi medicas dicit, easdemque ad regionum, locorum, aetatum, sexuum, habituum, consuetudinum, conditionum omnium diversitatem moderetur; quandoquidem ea artium inprimis dos sit, vel omnium nobilissima, ut ratione nitentes et stabili intellectus habitu firmatae, dare se in usum omnem queant, quidquid tandem obveniat novum, insolitum, dissuetum. Ita antecessores nostri Hippocrates, Galenus, Avicenna ad exemplar artis medicae, quam mente animoque puram atque exactam servabant, leges medicas, quas hodie habemus, litteris mandarunt, a nobis ad peculiares rerum occurrentium usus accommodandas." Ibid., p. 48.

${ }^{58}$ Ibid., p. 85.

${ }^{59}$ Ibid., pp. 84-5.
} 


\section{Rodrigo de Castro's Portrait of the Perfect Physician}

the view that it was worthwhile taking their opinions on curing diseases into account before going into other new ones. ${ }^{60}$

At the fourth level, De Castro placed the modern medical writers (neoterici), "men of our age and of the age of our elders, who were distinguished for their great wisdom, and had admirably improved, enlarged and illustrated the medical art with their commentaries" in different literary genres, such that their works should instruct and adorn the physician's library. ${ }^{61}$ The long list he provided is full of late medieval and Renaissance Latin medical authors - as well as, rather inconsistently, some late-ancient and other Arab writers-and his thread followed the different subject matters: anatomy, medicinal herbs, surgery, encyclopaedic compendia of medical knowledge, natural history, commentaries on Hippocrates, Galen and Avicenna, medical controversies, consilia and epistles, practical medicine, particular diseases, pharmacopoeias and antidotaries, and dietetics. ${ }^{62}$

Finally, on the fifth level De Castro placed authors of non-medical texts (poetry, agriculture, history and politics), again ancient as much as "modern" ones. Rather remarkably, at this point he praised the abundance of political writers in his age, and urged his readers to take as much advantage as possible from their works "to enlarge and improve the appearance of physicians' moral habits as well as medical science and art". ${ }^{63}$ While in this regard the influence of sixteenth-century Spanish neo-scholastic theologians, philosophers, and jurists like Benito Arias Montano, Juan Ginés de Sepúlveda, and even Francisco de Vitoria, is apparent in several passages of Medicus-politicus, their names were not always explicitly mentioned. ${ }^{64}$

\footnotetext{
60 " Est igitur praeposterum judicium eorum, qui Arabes et inde ductas familias tenebris opprimere conantur; quamvis enim tempore iniquo floruerunt, quo desertae ac sepultae meliores disciplinae penitus jacebant, digna tamen luce aeternaque memoria nobis reliquerunt. Non igitur ita unius Galeni auctoritati simus addicti, ut ejus verba jurare videamur, quod faciunt ii, qui omnes Arabes ac barbaros contemnunt; siquidem veris philosophis ac medicis ea libertas esse debeat, ut apum more optima quaeque eligant. Perinde enim est, quis dixerit, sive Graecus, sive Arabs, sive Hebraeus, sive Latinus fuerit, modo verum dixerit; non enim religionem docent, sed medicinam. Amicus Plato, amicus Socrates, magis amica veritas; et exillaudato solo laudatae fruges saepenumero proveniunt. Non desunt viri praestantes qui ordinem in scribendo, quem Galenum nullum servare constat, Averroi tribuant, et Avicennae, quorum incultam dictionem animadvertens Fernelius, superiori seculo eorum nomina obscurare decrevit, edito egregio atque eleganti opere, quo universam fere medicinam complexus est, absolute quidem, si De crisibus et diebus decretoriis tractationes ex Galeno aut aliunde suppleas; ac morborum curationes ex Raza vel Avicenna, et si novas aliquot opiniones, quas interdum inserit, dligenter examines.” Ibid., pp. 85-6.

61 "Quoniam autem nostra et majorum aetate viri exstiterunt praeclara sapientia conspicui, qui artem medicam, quisque in suo genere mirifice excoluerunt, amplificarunt, et suis commentariis illustrarunt; eorum etiam scripta evolvere medicus interdum debet, ita tamen, ut non quoslibet, sed eos duntaxat, in quorum operibus probata doctrina genium, et in scribendo dexteritas elucent, ad quae quatuor potissimum requiruntur, materia, res, nervus, et phrasis sive stylus; quibus si flores accedant, ad utilitatem fortasse parum, ad jucunditatem vero plurimum iuvant. Horum ego scriptorum aliquot breviter annotabo, ne in his, qui somnia sua potius, quam paeclaram aliquid scripserunt, sumptus et tempus medicus inaniter consumat, et bibliotheca ipsius paucis sed selectis instruatur, et exornetur potius quam oneretur." Ibid., p. 88.

${ }^{62}$ Ibid., pp. $88-91$.

63 "In quem usum pleraque etiam scripta politica nostro hoc politicorum feracissimo seculo prodierunt, in quibus omnibus semper diligenter observandum, si quae ad medicorum mores, vel ad medicam materiam, vel etiam ad medicam artem exornandam, amplificandamque inveniantur ...". Ibid., p. 91.

${ }^{64}$ See De Castro's references to the work Democrates (presumably, the Democrates primus o Dialogus de convenientia militaris disciplinae cum christiana religione) [1535] by Juan Ginés de Sepúlveda (1490-1573) (ibid., p. 53); and to Benito Arias Montano (1527-1598) (ibid.,p. 51); as well as his defence that the physician is obliged to help anybody who asks, irrespective of the patient's religion, on the assumption that all human beings of every nation are like each other because of the single Creation-against Epicurean theses, and in agreement with the ius gentium of Francisco de Vitoria (1483/6-1546): “... sed id monemus, ut quemlibet particularem auxilium
} 


\section{The Model University Training for a Medical Practitioner}

Given all this, it is not surprising that Rodrigo de Castro showed himself to be a firm defender of university education and that he considered it the best training for future medical practitioners. Strikingly enough, however, he introduced the Salamanca medical faculty as the model place for medical education on the basis of the supposed meticulous procedures that were followed there with respect to studies and exams, in contrast to the corrupted arrangements and frauds in other universities, whose identity he did not reveal. ${ }^{65}$ In addition to some positive, affectionate evocations of his early years in Salamanca, ${ }^{66} \mathrm{De}$ Castro also turned to the example of that Castilian university in order to solve a dubium about how to proceed in a difficult medical practical case, ${ }^{67}$ as well as to reinforce the idea that the risk of malpractice by future practitioners was minimized when the quality of their training scrupulously matched the rules laid down in the relevant university statutes. ${ }^{68}$

postulantem curandum suscipiat medicus, susceptumque omni sedulitate tractare studeat, sive Christianus ille sit, sive Judaeus sive Turca, sive Gentilis, omnes enim humanitatis lege sunt colligati, et omnes pariter a medico tractandos esse humanitas postulat. Est enim non solum ineptus verumetiam impius error eorum, qui in Epicuri dogmata lapsi, sativos homines fuisse putarunt, vel saltem quosdam populos terrae parentis indigenas esse crediderunt; quod quasi nobilitatis decus Atheniensibus tribuit Aristides, et, ut auctor est Bodinus, Altamerus auctoritate Taciti et aliorum Germanos in ipsa Germania genitos, nec ab ulla gente derivatos refert. Et Polydorus Virgilius Britannos in mediterraneis sitos, nec aliunde advenisse Caesarem secutus affirmat. Qui omnes magno errore et scelere obligantur, tum quod ea, quae Moyses divinus historicus in sacris literis de originibus testata relinquit, ineptissime oppugnant, tum etiam, quod nulla gentibus illis origine, quam a patrio solo tributa, eas ab aliorum societate, et amicitia omnium divellunt. Nam praeter caetera, quae divinum Moysen ad origines scribendas impulerunt, illud non minimum fuisse videtur, ut omnes homines, ad quos ea fama pervenisset, intelligerent, se esse consanguineos, et eadem generis conjunctione sociatos, quod ad amicitias stabiliendas plurimum valet. Adeo, ut pleraeque gentes et armati exercitus sola cognationis specie inimicitias deposuerint, qua etiam cognatione, et gentilitatis vinculo ductus medicus, omnes aequali fedulitate tractare tenetur. Immo ut omnis suscipio removeatur, nescio quid plus curae ac sollicitudinis in adversario adhibendum, ut malitiam, si qua in eo fuerat, bonitate superemus." Ibid., p. 168.

65 "Quae profecto via ad medicae artis perfectionem fuerit optima, ne qui primum in nido producti, ac prope implumes volare nituntur, in terram concidant, sed utroque, rationis scilicet atque experientiae, pede nixi secure progrediantur. Cursibus quidem in laudatissima Salmanticensi Academia quadriennium est constitutum, quo optimos professores alumni medicinae frequentare tenentur; tum deinde publico examine praestito, totius collegii medici suffragia experiri, quorum consensu si apti renuncientur, insignibus decorentur suis, nec tamen prius totius collegii testimonium scripto academiae sigillo comprobato illis conceditur, quam per biennium saltem alios praeeuntes in praxi sequantur, tunc vero testimonium illis tribuitur, quocunque tandem circumferendum, quo se judicatos ostendant, quibus fides in arte medica praestanda adhibendaque ab omnibus sit. At vero examen minime corrupte sit, sed servata lege magna cum integritate, ita ut plerique repulsam interdum patiantur, aut eorum approbatio suspendatur adhuc in annum aut biennium, quo ultra praescriptum tempus publicas lectiones frequentare teneantur, et si ne id quidem sufficiat, quotquot habuerit nigros calculos, in testimonio exprimi consuevit, ut ubique postea constare possit, cui tuto, et cui minus tuto homines suam salutem concredere debeant. Utinam talis mos in aliarum regionum academiis observaretur, et neque precibus neque pretio, sed juxta merita uniuscujusque promotio fieret, saepe etiam, uti audio, ex aliunde mutuatis declamationibus, ac thesibus medicis ab ipsis praeceptoribus, vel aliis consarcinatis." Ibid., p. 197.

${ }^{66}$ Ibid., pp. 68, 82, 249, 250.

67 "Major est ambiguitas, si quando dissidium incidit inter medicum et cognatum, qui durante dissidio morbo corripitur, teneaturne medicus illum non vocatus visitare. Cui affirmative respondeo, exemplo professorum Salmanticensium, inter quos etiamsi magnae interdum simultates intercedant, si quis tamen decumbat reliqui etiam dissidentes ob studiorum communitatem eum solent peramanter visitare, neque vero minor est cognationis quam studiorum consensus." Ibid., p. 164.

68 "Qua tamen in re antiqua gymnasiorum statuta, et quae hodie Salmanticae praesertim, religiose servantur, magno consilio condita conscientias promoventium onerant, quae expresse jubent, ne quem ad superiores dignitates scholasticas admittant, de quo universitas eruberscere possit.” Ibid., p. 199. 
Among the components of the training of the perfect physician, De Castro enumerated six of the seven disciplines making up the trivium and quadrivium (rhetoric, dialectics, arithmetic, geometry, music, and astrology); linguistic expertise in Latin, Greek, Arabic, and vulgar languages - the more the better, he stressed, so as to allow practitioners to communicate with patients from different nations in their own tongue; ${ }^{69}$ natural philosophy and moral philosophy; cosmography, anatomy and materia medica. ${ }^{70}$ De Castro's remarks on the utility of astrology and of moral philosophy deserve a little comment.

He categorically rejected divinatory judiciary astrology, which he defined as harmful, vain, superstitious, and condemned by the Holy Scriptures; and he did not appear to be very enthusiastic about the influences of the movements of the celestial bodies upon the healthiness of the air, the seasons of the year, the diseases of the living, and dearth. He appears to have been prepared to accept with no reservation only the medical value of astrological knowledge concerning critical days, bloodletting, and the administration of drugs. Yet, even here, he warned against those "superstitious and harmful" physicians and surgeons who paid more attention to the stars than to urine and the pulsations of the arteries. $^{71}$

On the other hand, De Castro emphasized the relevance of moral philosophy for medicine because it calmed the soul's disturbances, which he claimed to be not only the cause but also the symptom of many diseases. By referring to Galen (specifically, to Quod animi mores corporis temperamenta sequantur and De cognoscendis curandisque animi affectibus) as the authoritative source, De Castro held that diseases of the soul and diseases of the body communicated with each other, such that the care of the soul should not be neglected when bodily diseases are being treated. ${ }^{72}$

\section{De Castro's and Henríques' Portraits of the Perfect Physician: Resemblances and Contrasts}

Despite the resemblances of Rodrigo de Castro's portrait of the perfect physician to that depicted by his contemporary Henrique Jorge Henríques, ${ }^{73}$ there are not a few differences in their images that appear to be the result of their authors' disparate life experiences and careers. Certainly, both authors shared the condition of being Portuguese practitioners of Jewish lineage, as well as having been near contemporaries at Salamanca, although Henríques had begun his studies at Coimbra. Their further careers were, however, somewhat divergent. Indeed, Henríques developed his medical career in Castilian court settings under the protection of the powerful ducal house of Alba, and mostly lived in the area close to the Portuguese border. He appears to have remained outwardly Catholic

\footnotetext{
69 "Verum enimvero linguarum peritia omnino opus est, nam sermone Latino non potest medicus carere sine magna turpitudine, Graeco nec sine turpitudine, nec sine artis dispendio; non enim habemus materna lingua medicorum monumenta, sed Graece, Latine et pleraque Arabice; at enim nostra hac aetate linguarum etiam vulgarium notitia utilis, ut diversarum nationum et gentium aegrotos possit medicus visitare atque unumquemque sua lingua alloqui." Ibid., p. 54.

${ }^{70}$ Ibid., pp. 53-7.

${ }^{71}$ Ibid., pp. 57-64.

${ }^{72}$ Ibid., pp. $56-7$.

${ }^{73}$ On Henríques' work, see the bibliography referred to at note 3 above.
} 


\section{Jon Arrizabalaga}

until the end of his days in 1622 . Yet, his relatives and servants were then denounced to the Inquisition, prosecuted and imprisoned for two years, under the charge that they had buried his body according to Jewish rituals. ${ }^{74}$ Unlike Henríques, we have already seen that De Castro practised medicine in Portugal for only a short while before he migrated in the 1580s to the Low Countries, and in the 1590s to the Hanseatic republic of Hamburg, where he fully recovered the faith of his Jewish ancestors and became a prominent member of the Sephardic medical diaspora, not least as a result of his Medicus-politicus (Hamburg, 1614).

Henríques' Retrato (1595) reflects an ideal of a medical practitioner who was anchored in the prevailing values of Counter-Reformation Spain, although the author's dissatisfaction when confronted by many medical issues in late-sixteenth-century Castile, and his political and moral proposals to improve medical practice, at some point made his portrait of the perfect physician to be rather its reverse. Indeed, Henríques' attention was focused on criticizing such issues as the weakness of arts training; the low educational standards in Castilian medical faculties; practitioners' lack of travel experience; lack of control of health practices and practitioners by the political authority (Protomedicato); and the social promotion of inefficient practitioners at the expense of competent ones, who were excluded. Needless to say, this last issue meant an implicit denunciation of the serious discrimination stemming from the application of the "purity of blood" statutes to the selection of medical practitioners in charge of municipal and public jobs. ${ }^{75}$

By contrast, De Castro's Medicus-politicus represents a self-confident vindication of the public usefulness of university medicine, as well as of the political role for university medical practitioners in the city of Hamburg. It was written by a "new Jewish" physician who enjoyed a prominent socio-professional position, one that he did not then appear to have perceived as threatened. Although he claimed the original primacy of medicine for the Jews, he by no means appropriated this art for his nation; on the contrary, he was concerned to stress that medicine comes from God the Creator, that it was necessary and, in one way or another, it had been present among all the peoples in the world from the earliest times. Not surprisingly, it was his son Benedict de Castro who, about twenty years later, under growing anti-Jewish pressure, would advocate transforming the converso practitioner's stigma into a sign of honour, by claiming in his Flagellum calumniantium (1631) - a Jewish apology written as a reply to a libel against Portuguese Jewish practitionersthat the physician's "holy task" was a specifically Jewish venture. ${ }^{76}$

In his seventies, after a brilliant professional career, and with a new religious identity, De Castro appears to have wished fully to experience during the rest of his life the physical and temporal distance which may have given him relief from his memories of the difficulties he had gone through during his early professional days in Portugal until inquisitorial pressure finally pushed him to join the Sephardic diaspora in northern Europe. His unquestionable awareness through many channels (family contacts, testimonies by recent immigrants, and so on) of the personal and professional difficulties of his converso colleagues in the territories under the Hispanic monarchy did not prevent him from taking the medical faculty of Salamanca as the example of a university institution on a European scale

\footnotetext{
${ }^{74}$ Kamen, op. cit., note 11 above, p. 168.

${ }^{75}$ Arrizabalaga, op. cit., note 3 above, pp. 89-91.

${ }^{76}$ Ruderman, op. cit., note 2 above, pp. 299-305.
} 


\section{Rodrigo de Castro's Portrait of the Perfect Physician}

that could guarantee the training of the best physicians. This university was implicitly a central target of Henríques' criticisms about the low educational standards in the Castilian medical faculties, not least because its "purity of blood" statutes were far from mild.

\section{By Way of Conclusion}

Jews were given recognized residence rights in Hamburg in 1612, two years before Rodrigo de Castro published his Medicus-politicus. By then, he must have felt confident enough about his own social status in that Hanseatic city republic not to hide his Jewish religious beliefs. And during his later years De Castro chose fully to recover and live the religion of his ancestors-like his colleague and friend Abraham Zacuto (1575-1642) in Amsterdam, and probably inspired by him. In addition to his apparently lost work on Jewish excommunication, De Castro's deep Jewish religiosity at that period can be inferred from at least three major features of his Medicus-politicus, first, his knowledgeable use of the Holy Scriptures that he repeatedly resorted to as an authoritative source for this work; second, his insistence on the holy aspects of medicine regarding the divine origins of this art and the way he understood medical practice; and third, his familiarity with, concern about, and approval of the magical powers of the cabala as a therapeutic resource. ${ }^{77}$

Anti-Semitism was widespread in Hamburg in 1614. Yet those medical practitioners belonging to the well-off and then still tiny Sephardic minority would not begin to suffer directly from the xenophobic passions of the Lutheran majority until later decades. In this context, De Castro's strong alignment with the Hippocratic-Galenic-Avicennian medical tradition may have been not only a consequence of his university education in midsixteenth-century Salamanca, but also a strategy by him to reinforce before the Hamburg political authorities the probity of the Sephardic medical elite's understanding and practice of medicine. In this way he avoided the risk that his medical practice was identified with that of German Jewish practitioners who, according to the extremely negative cliché then prevailing in Germany, were considered to be professionally incompetent, avaricious, murderous quacks and wizards whose apparent talent for medical practice was attributed to a pact with the devil. ${ }^{78}$

De Castro, however, did not stop here, and he also chose to keep his distance from the kind of medicine that a great number of other contemporary health practitioners were carrying out in Hamburg and, presumably, in the whole of Germany. Indeed, in addition to having portrayed a great many irregular practitioners and practices that his perfect physician was opposed to, he launched a harsh attack on Paracelsus and the "sect of chemists", among whose followers may have been most of those Christian practitioners who competed with the Jewish ones for the same medical market. His invectives against Paracelsus, who had objected to the idea that Jews possessed more talent for medicine than Gentiles, and had himself been committed to an exclusively Christian ministry for this art, ${ }^{79}$ led De Castro to counter-attack by insisting that Paracelsus had resorted to necromancy in order to prepare some medicinal remedies.

\footnotetext{
${ }^{77}$ De Castro, op. cit., note 13 above, pp. 224-9; Ruderman, op. cit., note 2 above, pp. 297-9.

${ }^{78}$ Efron, op. cit., note 30 above, pp. 46, 58.

${ }^{79}$ De Castro, op. cit., note 13 above, p. 14; Ruderman, op. cit., note 2 above, pp. 245-6.
} 


\section{Jon Arrizabalaga}

De Castro defined his perfect physician as "male, virtuous, and expert in medicine". To him Hippocratic-Galenic-Avicennian medicine was the basis for the best medical practice; and the medical faculty of Salamanca a kind of model university school for training the best practitioners. As usual among most sixteenth- and seventeenth-century Iberian converso practitioners, De Castro's medical profile was characterized by a remarkable eclecticism that was respectful towards ancient, medieval and Renaissance medical authorities, and included a positive re-evaluation of the Arab legacy, but which openly rejected medical sects, particularly Paracelsianism. ${ }^{80}$ His esteem for the Arab medical authorities was typical of the medical neo-scholasticism prevailing in late-sixteenth- and early-seventeenth-century Spanish and Italian universities. Yet, I wonder to what extent this appreciation of Arab medicine was also intended by De Castro and other Jewish practitioners as a tacit vindication of their own medical cultural tradition and converso identity, so closely related to the Arab during the Middle Ages. ${ }^{81}$

Last but not least, the fact that the literary genre of the "perfect physician" dealt with what practitioners "should be", their intellectual and moral ideals, and the terms of their professional education and practice, meant that for the converso minority it was not only a public window where they could project their professional aspirations, but also a suitable way to express nonconformist driving forces in the medical arena of early modern European societies, which had been completely dominated by Christian elites (both Catholic and Protestant), who had excluded religious minorities to a greater or lesser extent. Given the assiduousness of converso practitioners in cultivating this genre, one might, for instance, wonder whether behind De Castro's decision to write and publish a work like Medicus-politicus there was a desire to differentiate themselves from their "old Christian" colleagues. But Jewish practitioners' images of the ideal medical practitioner nevertheless differed from each other-perhaps no less than those of their Catholic and Protestant counterparts.

\footnotetext{
${ }^{80}$ This medical conservatism was still alive in the second half of the seventeenth century. In this respect there is the striking case of the marrano Diego Mateo Zapata (1664-1745) whose medical thought evolved from a radical Galenism in the early years of his career (at least, until 1693) to become a champion of chemical medicine. See José Pardo Tomás, El médico en la palestra. Diego Mateo Zapata (1664-1745) y la ciencia moderna en España, Valladolid, Junta de Castilla y León, 2004, pp. 129-68.

${ }^{81}$ Andrés Laguna (c.1511-1559) appears to be one of the few exceptions to this rule. His strong alignment with medical Hellenism might have been due not only to his medical education in Paris, where this movement was then most aggressive, but also to a probable rejection of his own Jewish identity (see Caro Baroja, op. cit., note 2 above: vol. 2, pp. 188-9). Laguna's determination to obtain titles could also be ascribed to a desire to wipe away the traces of his converso lineage (see Arrizabalaga, op. cit., note 2 above, pp. 319-20).
} 